\title{
LOGIKA MIHAJLA MARKOVIĆA KAO FILOZOFSKA PROPEDEUTIKA U SREDNJOJ ŠKOLI ${ }^{1}$
}

\begin{abstract}
APSTRAKT: Autorka u radu ispituje mogućnost uloge logike kao filozofske propedeutike u srednjoškolskom sistemu obrazovanja. Ukoliko se logika shvata kao nauka koja se bavi osnovnim elementima i principima mišljenja, onda je razumljivo zašto se pre pristupa izučavanju predmeta filozofije u završnoj godini srednje škole mora pažljivo pristupiti izučavanju predmeta nauke logike. Stoga ćemo se u radu najpre posvetiti istraživanju mogućnosti da se logika razume kao filozofska propedeutika kako kroz preispitivanje istorijske pozicije logike tako i kroz problematizaciju samog pojma filozofije. Nakon toga, daćemo kratak prikaz udžbenika logike Mihajla Markovića za gimanziju i treći razred pravno-birotehničke škole, kao osnovnog nastavnog sredstva u procesu nastave Logike, da bismo videli na koji način se sadržaj logike može približiti učenicima srednjih škola, kao i da li je Mihajlovićev udžbenik adekvatan za takav cilj. Naposletku, ispitaćemo važnost uloge koju logika ima u razvoju kritičkog mišljenja i način na koji može da doprinese tom razvoju, te tematizovati najbolje nastavne metode kojim se može pristupiti nastavi Logike u tu svrhu.
\end{abstract}

Ključne reči: logika, filozofija, kritičko mišljenje, pojam, nastava, metodologija, nauka.

\section{THE LOGIC OF MIHAJLO MARKOVIĆ AS A PHILOSOPHICAL PROPAEDEUTIC IN SECONDARY SCHOOL}

ABSTRACT: In the following paper, we will examine the possibility of the role of logic as a philosophical propaedeutic in the secondary school system of education. If we understand logic as a science whose primary objects are basic elements and principles of thinking, then it is understandable why before studying the subject of philosophy in the final year of high school one must carefully approach the study of the subject of the science of logic. Therefore, in this paper we will first focus on exploring the conditions for the possibility of the science of logic to be understood as philosophical propedeutics, both through reexamining the historical position of logic and through problematizing the notion of philosophy. Thereafter, we will give a short analysis and presentation of the textbook of Mihajlo Marković's logic for grammar schools and the third grade of the legal high school

\footnotetext{
${ }^{1}$ Tekst je proizašao iz seminarskog rada na masterskim studijama Filozofije na Filozofskom fakultetu Univerziteta u Novom Sadu iz predmeta Metodika filozofske propedeutike kod doc. dr Une Popović.
} 
as a basic teaching tool in the teaching process of logic to see how the content of the science of logic can be approached by high school students, as well as whether Mihajlović's textbook is adequate for such an aim. Finally, we will examine the importance of the role that logic plays in the development of critical thinking and discuss the best teaching methods that can be used to teach logic for this purpose.

Key words: logic, philosophy, critical thinking, notion/concept, teaching, methodology, science, propaedeutic.

\section{LOGIKA KAO FILOZOFSKA PROPEDEUTIKA}

Logika, kao pretpostavka sveg mišljenja, jedna je od važnijih naučnih disciplina sa kojma se čovek susreće tokom svog života. Bez obzira da li je reč o teorijskoj logici u kojoj je mišljenje mišljeno uopšte, pa se tako misle principi, zakoni i oblici mišljenja, i njegovo poreklo i priroda, ili je, pak, reč o praktičnoj logici, odnosno primenjenoj logici koja se bavi propisivanjem normi mišljenja $u$ nekoj posebnoj oblasti znanja (Aćimović 2007: 14), logika je kao takva nezaobilazna u svakoj sferi ljudske delatnosti.

Ona, međutim, ne pripada nekoj konkretnoj nauci, već se samim svojim određenjem nauke koja se bavi principima sveg mišljenja svrstava u jednu vrstu filozofske propedeutike. Filozofska propedeutika nam svojim imenom govori da se radi o jednom uvodu u filozofiju, o pripremi za filozofsko mišljenje. To filozofsko mišljenje možemo okarakterisati kao problemski orijentisano (Smiljanić 2016: 35). Glavno ishodište filozofije jesu nerešivi problemi, odnosno aporije u koje se čovek zapliće kada reflektuje sopstvenu poziciju i svoj odnos prema svetu. Da bismo sebi prokrčili put kroz tu filozofsku teritoriju, na početku nam je potrebna logika kao sistem uputstava, pravila, principa, normi valjanog mišljenja, ili mišljenja koje mora biti istinito.

Potvrdu za ovako shvaćenu logiku, kao osnovu za početak bavljenja filozofijom, možemo pronaći i u istoriji filozofije. Tako je kod Aristotela

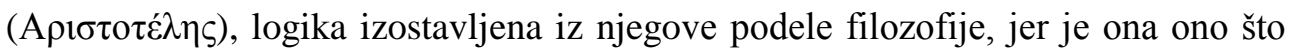
filozofiji prethodi i omogućava je, odnosno razumljena je kao veština ispravnog zaključivanja. Da bi mišljenje moglo da spozna objektivnu stvarnost i da dođe do bilo kakvog istinitog saznanja, ono mora biti postavljeno na sigurne temelje i principe, stoga i Aristotelovo delo $u$ kojem se bavi veštinama ispravnog zaključivanja i upotrebom razuma kasnije dobija naziv Organon, odnosno oruđe. Kod Kanta (Immanuel Kant), pak, logika je razumljena kao apriorna nauka o nužnim zakonima mišljenja svih predmeta uopšte, nauka o pravilnoj upotrebi uma, po aprirori principima kako razum treba da misli (Aćimović 2007: 12). Dakle, i tu je logika shvaćena kako osnova i priprema za filozofsko istraživanje. 
Jasno je, stoga, da logika ima opravdan status filozofske propedeutike. Imajući to u vidu, jasno je da u sistemu obrazovanja, u srednjim školama $u$ Republici Srbiji, predmet Logike vremenski dolazi pre susreta učenika sa Filozofijom u završnoj godini gimnazije i srednjih stručnih škola. Cilj nastave Logike u srednjoj školi jeste da se učenici upoznaju sa osnovnim elementima i principima mišljenja, da shvate odnos ispravnog i istinitog mišljenja, jezika i mišljenja i drugih problema saznanja, kao i uslova uspešne komunikacije, da se osposobe za primenu metodologije istraživanja i razviju sposobnost za sistematsko, samostalno i kritičko mišljenje. Nakon uspešnog savladavanja nastave Logike, nastava Filozofije bi učenicima trebalo da omogući da razumeju filozofske probleme i njihova rešenja na primerima najvećih dostignuća filozofske misli, kao i da steknu sposobnosti pozitivnim transferom za razumevanje drugih teorijskih i praktičnih problema, te da stiču uvid u opšte teorijske i humanističke tokove mišljenja koji su uobličavali određene istorijske epohe i čine osnovu savremenih humanističkih i kritičkih orijentacija i time unapređuju obrazovanje (Kuburić 2010: 189).

U ovom radu ćemo se posvetiti prikazu Udžbenika logike za gimnaziju $i$ treći razred pravno-birotehničke škole, autora Mihajla Markovića, u izdanju Zavoda za udžbenike i nastavna sredstva iz 2000. godine. Markovićev udžbenik je u upotrebi u školskom sistemu po odobrenju Ministarstva prosvete Republike Srbije još od 1992. godine. Cilj nam je da na primeru vidimo na koji način dolazi do prvog susreta učenika sa naukom logike, kao i kako je koncipiran sam sadržaj ovog nastavnog predmeta.

Mihajlo Marković je jedan od najznačajnijih srpskih filozofa XX veka, sa velikim doprinosom nauci logike. Logika je kod njega razumljena kao ispitivanje odnosa mišljenja i sveta (Aćimović 2015: 306). Središnja tačka Markovićevog zasnivanja logike nalazi se u otklonu od tadašnje staljinističko-marksističke logičke paradigme i vraćanju tada odbačenoj formalnoj logici, ali u interpretaciji dijalektičkog materijalizma, za šta u tom momentu nije postojao gotov obrazac kojim bi se moglo poslužiti. Tako shvaćena logika jeste nauka o zakonima mišljenja i procesu saznanja istine o objektivnoj stvarnosti. Ona sadržinski obuhvata predmet i značaj logike, dakle u pitanju su formalna i dijalektička logika, zatim učenje o pojmu, sudu i zaključku, dok su na kraju dati opšti postupci naučnog istraživanja, a sadržinska pretpostavka logike jeste teorija saznanja, jer logika i jeste jedan oblik saznanja.

U narednom poglavlju ćemo se posvetiti analizi samog udžbenika, da bismo na kraju videli na koji način takav sadržaj pomaže učenicima u razvijanju 
kritičkog mišljenja i pripreme za predmet Filozofije, kao i koja nastavna sredstva mogu biti adekvatna u takvoj nastavi Logike.

\section{LOGIKA MIHAJLA MARKOVIĆA KAO UDŽBENIK ZA SREDNJU ŠKOLU}

Mihajlo Marković svoju Logiku za III razred gimnazije $i$ pravnobirotehničke škole otpočinje jednim uvodom u kojem daje istorijski ostvrt na postanak i razvoj logike, obuhvatajući period od Aristotela, koji je u Organonu prvi sistematski izložio logiku kao oruđe za veštinu ispravnog zaključivanja, pa sve do simboličke logike Bertranda Rasela (Bertrand Russell) i Alfreda Vajtheda (Alfred Whitehead). Nakon uvoda prelazi na tematizovanje odnosa logike, filozofije i nauke, gde je logika, kao nauka o istraživanju uslova saznanja istine, razumljena kao deo filozofije, a filozofija se poima kao nauka u onoj meri u kojoj se služi metodama racionalnog sistematskog mišljenja (Marković, 2000: 5). Značaj logike Marković je učenicima predstavio u tome što njeno poznavanje vodi do sposobnosti kritičkog mišljenja, ukoliko se pridržavamo logičkih pravila i izbegavamo logičke greške. Autor udžbenik Logike započinje jednim kratkim istorijskim prikazom istorije logike i smeštanjem logike $\mathrm{u}$ jedan misaoni okvir filozofije i nauke, da bi učenike upoznao sa njenim osnovnim zadacima, pre nego što se upusti u sam logički sadržaj.

Ukoliko je cilj logike da čovek stekne sposobnost istinitog saznanja, onda se mora problematizovati i sam pojam saznanja. Saznati neku stvar za M. Markovića podrazumeva postati svestan njenih bitnih svojstava i odnosa prema drugim pojavama (Marković 2000: 8). Kriterijumi tako razumljenog saznanja jesu jasno jezičko formulisanje onoga što pretendujemo da znamo, sposobnost utvrđivanja iskustvenih uslova u kojima je moguće identifikovati predmet koji smo po našem uverenju saznali, i na kraju, sposobnost objašnjenja saznatog predmeta (Marković 2000: 8). Izvore saznanja Marković vidi u čulnosti, razumu i intuiciji, a vrste saznanja su svedočanstvo, menjanje i verovanje. Naravno, potrebno je i tematizovati pojam istine, kao i aktuelne teorije istine, pa tako Marković učenike upoznaje sa elementima Aristotelove teorije korespodencije, uvodi i teoriju evidentnosti, kao i teoriju verifikacije, gde se osvrće na logički empirizam i pragamtizam, te na kraju tematizuje dijalektičku teoriju istine.

\subsection{Elementi mišljenja}

Nakon opisanog kratkog uvoda, celina udžbenika podeljena je na dva dela - prvi deo se bavi elementima mišljenja, odnosno pojmom, sudom i zaključkom, a 
drugi deo je posvećen učenju o metodi, gde se ispituju oblici procesa saznanja u njihovoj celovitosti i praktičnoj primeni u nauci. Deo logike koji se bavi elementima mišljenja naziva se elementarna logika, koja sadržinski obuhvata misaone oblike pojma i suda, te misaonu radnju zaključka. Pojam, pak, Marković definiše kao ,istovetne elemente iskustva raznih ljudi pod različitim uslovima koje konstantno vezujemo za jednu reč.” (Marković 2000: 22). Navedena definicija pojma na pomalo opisni način govori o pojmu, bez strogih logičkih određenja, verovatno u cilju približavanja rečnika logike učenicima koji se sa njom prvi put susreću. U nastavku, Mihajlo Marković na sažet i koncizan način govori o obrazovanju pojmova, njihovim međusobnim odnosima, obimu i sadržaju pojma, kao i o njihovim vrstama, pa tako postoje pojedinačni, posebni i opšti, jasni i nejasni, konkretni i apstraktni pojmovi. Svaka od ovih oblasti istraživanja pojma potkrepljena je slikovitim primerima.

Pre ispitivanja misaonog oblika suda, posebno poglavlje posvećeno je istraživanju pojmova definicije i klasifikacije. Definicija je shvaćena kao iskaz kojim se određuje sadržaj jednog pojma (Marković 2000: 32). Za pravilno definisanje pojma potrebno je znanje o vrstama i metodama definisanja, kao i o specifičnim pravilima koja se moraju poštovati u procesu definisanja.

Treći odeljak odnosi se na misaonu radnju suđenja, odnosno njen misaoni oblik - sud. Naznačeno je da se tek sa sudom može govoriti o funkciji istinitosti, jer pojam ne može biti istinit ili lažan, za to je potrebna veza dva ili više pojma. Tako je istinit sud onaj čija veza pojmova odgovara povezanosti samih objektivnih stvari i svojstava na koje se dati pojmovi odnose (Marković 2000: 40). Struktura suda sastoji se od predmeta o kome se govori - subjekt, onog što se o predmetu govori, odnosno predikata, i na kraju same veze između subjekta i predikata kopule. U odnosu na vrstu, autor sudove deli po kvalitetu (tvrđenje, poricanje), po opštosti ili kvantitetu (pojedinačni, posebni ili opšti), po strukturi (prosti ili složeni), modalitetu (problematički, asertorički, apodiktički), i na kraju po saznajnoj vrednosti (sudovi neposrednog opažanja, uviđanja veza i odnosa, utvrđivanja suštine predmeta, utvrđivanja vrednosti) (Marković 2000: 42-44). Kao i u slučaju pojma, svaka vrsta i oblik suda potkrepljena je iscrpnim primerima, u cilju lakšeg razumevanja samog sadržaja.

Nakon ispitivanja pojma suda, logički završetak izlaganja osnovnih misaonih oblika i radnji jeste misaona radnja zaključivanja, odnosno misaoni oblik zaključka. Zaključivanje je oblik mišljenja, misaona radnja u kojoj se dovode u vezu dva ili više suda, tako da se iz te veze izvede jedan novi sud (Marković 2000: 54). Misaoni oblik koji proističe iz toga naziva se zaključak. Marković vrste zaključivanja deli na neposredne i posredne, gde u neposredne spadaju intuicija, 
zaključivanje po opoziciji i analogiji. Sa druge strane, u posredne oblike zaključivanja spadaju indukcija i dedukcija, kojima Marković posvećuje posebnu pažnju. On prikazuje oblike potpune i nepotpune indukcije, u nastavku se bavi njenim logičkim problemima, te na kraju navodi uslove prihvatljivosti induktivnog zaključka. Kada je u pitanju deduktivno zaključivanje, pored njegovih opštih karakteristika, M. Marković detaljno razvija Aristotelovu teoriju silogizma, sa primerima i zadacima upućenim učenicima u cilju bržeg i lakšeg savladavanja osnovnih figura silogizma.

Pre nego što pređe na drugi deo udžbenika, metodologiju naučnog istraživanja, autor se na kratko osvrće na pojam dokaza, proces dokazivanja $i$ logičke greške. Ispituje elemente i osnovne vrste dokaza, koje deli na racionalne $\mathrm{i}$ empirijske, direktne i indirektne, sintetičke i analitičke. Pod logičkim greškama podrazumevaju se sofizmi i paralogizmi, odnosno takvi zaključci i dokazi koji prividno izgledaju tačni, ali su u stvari lažni (Marković 2000: 90). Tako se logičke greške mogu praviti u odnosu na pravila mišljenja, u odnosu na iskustvene činjenice, ali mogu nastati i kao posledica jezičkih konfuzija.

Time se završava celina posvećena elementima mišljenja, uz obuhvatanje osnovnih misaonih oblika i radnji, kao i osnovnih pravila za ispravno funkcionisanje mišljenja. Ta celina logička je osnova drugog dela udžbenika, posvećenog opštoj metodologiji nauke, gde se ispituju oblici procesa saznanja $u$ njihovoj celovitosti i u praktičnoj primeni u nauci. Na taj način, kooperacijom logike i metodologije u srednjoškolskoj nastavi, dolazi do jačanja interesa za proučavanje metodoloških osnova prirodnih i društvenih nauka, čime logika može do kraja da ispuni svoju propedeutičku funkciju (Smiljanić, 2012: 72).

\subsection{Opšta metodologija nauke}

Drugi deo udžbenika otpočinje analizom jezika naučnih teorija, gde Marković jezik razumeva kao specifičan sistem simbola koji imaju utvrđeno značenje, koji se mogu menjati, međusobno spajati i zamenjivati po određenim pravilima, i ne moraju biti obavezno slični objektima koje označavaju (Marković 2000: 99). Funkcije jezika jesu da obavesti o činjeničnom stanju, da izrazi osećanja, da utiče na ponašanje drugih i da uspostavi i učvrsti društvene veze, ali te funkcije u običnom govoru nikada nisu izolovane jedne od drugih. U skladu sa tim uslovi uspešene komunikacije jesu: 1. da u svakom procesu komunikacije bude jasno koju funkciju vrše upotrebljeni jezički izrazi; 2. da izrazi naučnog jezika zadovoljavaju i teorijski i praktični kriterijum smisla; 3. da u toku datog procesa komunikacije svaki simbol treba da ima samo jedno značenje; 4. da ključni termini 
budu definisani; 5. da bi tumačenje iskaza bilo adekvatno, treba uzeti u obzir ceo kontekst u kom se on pojavljuje i najzad 6. da u datom komunikativnom procesu značenja reči ostanu nepromenjena (Marković 2000: 102-104).

Drugi odeljak M. Marković posvećuje teorijskoj pripremi istraživanja, koja se sastoji od šest koraka. Najpre je reč o teorijskim zadacima u pripremnoj fazi istraživanja, nakon čega sledi utvrđivanje problema, zatim ispitivanje uslovljenosti karaktera istraživanja vrstom problema, konkretizovanje problema, određivanje pojmovnog okvira istraživanja, okvir pretpostavki istraživanja, te na kraju i samo istraživanje. Logičkim sledom, iz drugog poglavlja se prelazi na poglavlje koje se odnosi na utvrđivanje naučnih činjenica. Otpočinje se njihovom definicijom, da bi se nakon toga izložile osnovne metode kojima se one mogu utvrditi - naučno posmatranje, eksperiment, ispitivanje uslova adekvatnog opažanja i merenje.

Nakon utvrđivanja naučnih činjenica, autor udžbenika tematizuje pojam naučnog objašnjenja. Za njega, naučno objašnjenje jedne pojave znači pokazati da je ona nastala nužno iz nekog prethodnog činjeničnog stanja, odnosno da stavovi koji opisuju tu pojavu slede iz nekog utvrđenog naučnog zakona i iz nekih drugih stavova koji adekvatno i objektivno opisuju prethodne činjenice (Marković 2000: 119). Sa druge strane, naučna hipoteza je takva pretpostavka opšteg karaktera kojom pokušavamo da objasnimo neki skup činjenica i koja zahteva svoju praktičnu potvrdu da bi bila usvojena kao zakon ili kao teorija. U tipove naučnog objašnjenja Marković svrstava statističko, genetičko i uzročno, sa tim što posebnu pažnju posvećuje uzročnom objašnjenju analizirajući pojam uzročnosti i izlaganjem metoda za ispitivanje uzroka Džona Stjuarta Mila (John Stuart Mill).

Prateći logičku nit razvoja metodologije nauke, Mihajlo Marković dolazi do pojma naučnog zakona, koji razumeva kao objektivne, stalne, opšte i nužne odnose među pojavama stvarnosti (Marković 2000: 127). Stoga, naučna teorija jeste celovito objašnjenje jedne grupe pojava koje u sebi uključuje i zakone i formulaciju osnovnih konkretnih uslova (činjenica) iz kojih je delovanjem navedenih zakona grupa pojava u pitanju nastala, a naučni sistem predstavlja jedinstveni skup znanja (činjenica, zakona, teorija) koja su međusobno povezana i sređena na osnovu izvesnih principa (Marković 2000: 129).

Ovim se zaokružuje sistem nauke logike sačinjen od osnovnih elemenata i radnji mišljenja sa jedne strane, i osnovnih procesa saznanja i opšte metodologije nauke sa druge. Mihajlo Marković ovde ne završava svoj udžbenik, već poslednji odeljak posvećuje istraživanju osnovnih filozofskih metoda.

Ovo je razumljivo ukoliko imamo u vidu da logika kao nastavni predmet u srednjoj školi predstavlja svojevrsnu filozofsku propedeutiku, pripremu mišljenja za suočavanje sa osnovnim filozofskim problemima i metodama izloženim u 
nastavnom predmetu Filozofije. Nakon predstavljanja osnovnih principa i pravila mišljenja, u poslednjoj oblasti koja se obrađuje na nastavi, obično prezentovanoj na kraju školske godine, upoznavanje sa osnovnim metodama filozofije na pravi način predstavlja mogućnost da učenici primene naučeno i steknu iskustvo kritičkog mišljenja pre samog ulaska u Filozofiju.

Kao osnovne filozofske metode autor učenicima predstavlja analitičkoempirijski metod, kojim obuhvata filozofski pravac empirizma i neke autore analitičke orijentacije u savremenoj filozofiji. Tako on govori o Vitgenštajnu (Wittgenstein) i Karnapu (Carnap), izlažući njihov metod filozofske analize (Marković 2000: 132). Pored analitičko-empirijskog metoda, Marković se bavi heremenutičkim metodom, a učenike upoznaje sa Šlajermaherom (Schleiermacher) i Diltajem (Dilthey). Zastupljen je i fenomenološki metod Edmunda Huserla (Edmund Husserl), a udžbenik se završava osvrtom na kritičko-dijalektičku metodu.

U ovom kratkom prikazu Markovićevog udžbenika videli smo način na koji on pokušava da uklopi celinu logičkih elemenata na način koji bi učenicima, koji se prvi put susreću sa pojmom i predmetom logike, bio pre svega jasan i razumljiv, ali i interesantan. Razumevajući logiku kao nauku o uslovima objektivnog saznanja istine, Marković je kroz svoj udžbenik pokušao da predstavi osnovna polazišta sa kojih se učenici mogu dalje kretati i upoznavati sa filozofijom.

Međutim, neke recepcije ovog udžbenika nisu bile u potpunosti pozitivne. Tako je, na primer, Svetlana Knjazeva u svojoj recenziji Logike prigovorila Mihajlu Markoviću zbog načina na koji on određuje pojam, kao i određenjima sinteze suprotnosti identiteta i razvoja (Aćimović, 2015: 412). Pored nje, i Bogdan Šešić je prigovorio da, iako je ovaj udžbenik logike najbolji kod nas, on, pak, „sadrži samo osnovne teze za jedan obimniji i viši udžbenik logike" (Aćimović, 2015: 413). Istina, Šešić je i sam naknadno napisao univerzitetski udžbenik logike, na sličnoj poziciji kao i Mihajlo Marković, poziciji dijalektičke logike, koji pored osnovnih oblika mišljenja i procesa koji se odvijaju u mišljenju, sadrži i razmatranja o samoj prirodi jezika, kao i osnove simboličke logike, te osnovne logičke sisteme (Šešić, 1977: 5-8). No, činjenica je da je Markovićev udžbenik prvenstveno namenjen učenicima srednjih škola, koji prvi put dolaze u dodir sa naukom logike i njenim pojmom, te kao takav pruža adekvatan sadržaj, na način koji je primeren učenicima.

$\mathrm{Na}$ kraju, u narednom poglavlju preostaje nam da vidimo na koji način izučavanje predmeta Logike pomaže učenicima u razvijanju kritičkog mišljenja, kao i koje nastavne metode jesu najadekvatniji pristup za ovakvu vrstu predmeta. 


\section{LOGIKA KAO PREDUSLOV ZA RAZVOJ KRITIČKOG MIŠLJENJA}

Videli smo u prethodnom poglavlju na koji način je struktuiran udžbenik iz Logike za srednju školu, na primeru udžbenika Mihajla Markovića. Udžbenik u sebi obuhvata dva dela, deo elementarne logike, odnosno ispitivanje osnovnih elemenata i principa mišljenja, i deo koji je posvećen opštoj metodologiji nauke, kao delu primenjene logike. Ukoliko imamo u vidu ciljeve nastave Logike koje smo naveli na početku rada, dakle da se učenici upoznaju sa osnovnim elementima i principima mišljenja, da shvate odnos ispravnog i istinitog mišljenja, jezika i mišljenja i drugih problema saznanja, kao i uslova uspešne komunikacije, da se osposobe za primenu metodologije istraživanja i razviju sposobnost za sistematsko, samostalno i kritičko mišljenje, vidimo da udžbenik Mihajla Markovića ispunjava sve sadržinske uslove koji su neophodni učeniku trećeg razreda srednje škole da krene u uvežbavanje svog mišljenja.

Međutim, nije dovoljno da učenici samo dobiju teorijsko znanje iz predmeta Logike, već i da to teorijsko znanje nauče da primene. Primena logike koja je učenicima neophodna može se svesti na, uslovno rečeno, četiri osnovne oblasti: 1. da učenici nauče kritički da razmišljaju; 2. da primene logičko razmišljanje na govor i pisanje; 3. da se osposobe za metodološko istraživanje, prikupljanje, analizu i procenu određenih informacija i 4. da poboljšaju svoje sposobnosti u oblasti digitalizacije i računanja, ukoliko govorimo o primeni matematičke logike, što je u današnjem vremenu posebno važno (Bouhnik, Giat, 2009: 4). Naravno, jasno je da su oni i pre nastave Logike u svom školovanju koristili određena pravila mišljenja, ali oni to u najvećem broju slučajeva nisu reflektovali kao pravila mišljenja. To je za njih nešto prirodno, zdravorazumsko, nešto što svakodnevno upotrebljavaju. Međutim, važno je da oni postanu svesni postojanja određenih pravila po kojima mišljenje funkcioniše, ponekad na drugačiji način od onoga na šta su obično navikli. To je važno, pre svega, da bi u njihovom konačnom susretu sa Filozofijom, odnosno filozofskim mišljenjem, koje je u većini slučajeva aporetičkog karaktera, imali svest o načinima na koje mišljenje funkcioniše, te na taj način uspeli da razvijaju sopstveno mišljenje u kritičkom pravcu.

No, šta znači razvijati mišljenje u kritičkom pravcu, odnosno šta bi tačno podrazumevalo kritički misliti? Nil Braun (Neil Browne) i Stjuart Kili (Stuart Keeley) u njihovoj knjizi Postavljanje pravih pitanja (Asking the Right Questions) tvrde da se pod kritičkim mišljenjem podrazumeva svest o skupu međusobno povezanih kritičkih pitanja, zatim sposobnost da se ista postavljaju i da se na njih daje primeren odgovor, te naposletku i želja za konstantnim postavljanjem pitanja 
kroz koja se dolazi do uočavanja međusobnih povezanosti određenih stvari koje su u pitanju (Browne, Keeley 2007: 16).

Postavlja se pitanje na koji način se učenici mogu uvežbavati u razvijanju kritičkog mišljenja kada steknu teorijsku osnovu? Metod kojim se nastava odvija tu igra odlučujuću ulogu. Govoriti o nastavnim metodama znači, pre svega, govoriti o nastavi s aspekta postavljenih ciljeva i načina za njihovo ostvarenje (Kuburić 2004: 75). Sam cilj nastave zavisi od sadržaja samog nastavnog predmeta. Stoga, ukoliko je krajnji cilj nastavnog predmeta Logike da kod učenika razvija sposobnost kritičkog mišljenja, onda se nastavne metode moraju na svaki način prilagoditi tom cilju. Dakle, u nastavi se ne može koristi samo metoda usmenog izlaganja, u kojoj nastavnik drži monolog dok učenici zapisuju beleške, već se nastavna metoda mora najpre orijentisati na interaktivnu vrstu nastave. Ključnu ulogu u nastavi logike moraju imati, pre svega, primeri i zadaci na kojima učenici moraju da primene prethodno usvojeno teorijsko znanje. Postavljanje pitanja i odgovora, takođe, može biti dobar način na koji učenici mogu da usvoje novo gradivo, u smislu da do novih sadržaja dolaze putem upotrebe sopstvenog razuma, a ne pukim prenošenjem informacija i znanja od strane nastavnika. Nastavnikova uloga jeste da učenike vodi kroz materiju, usmeravajući ih u pravcu odgovora, a ne da im prosto prezentuje činjenice. Ovakva vrsta nastave pogodna je ne samo u oblasti Logike, već i u oblasti Filozofije (štaviše, tamo je neophodna, setimo se samo sokratske metode razgovora).

Sada nam preostaje još da vidimo kako razvoj kritičkog mišljenja utiče na učenike, odnosno kako se manifestuje u njihovom načinu razmišljanja. Naime, utvrđeno je da razvoj kritičkog mišljenja utiče na kvalitet njihovog metoda učenja, posebno na njihovu metodu procenjivanja naučne verodostojnosti gradiva i ideja, kao i na pronalaženje mogućnosti najadekvatnije primene tih ideja, te na sposobnost uvida koji se zaključci mogu izvesti iz zadatog teksta (Kalin 1982: 36). Pored toga, razvijanjem kritičkog mišljenja putem nastave logike učenici stiču sposobnost nalaženja zajedničkog osnova u različitim idejama, dobijaju mogućnost preciznijeg izražavanja vlastitih misli i samostalne artikulacije određenih ideja, te sposobnost pronalaženja sopstvenih primera kada se to od njih zahteva. Vidimo, dakle, da je za razvijanje kritičkog mišljenja u nastavi Logike najbolji pristup problemskog karaktera, odnosno putem rešavanja problema, i to ne samo u nastavi Logike, kao filozofske propedeutike, već je to neophodno i za nastavu same Filozofije, ukoliko želimo da joj pristupimo na pravi način. 


\section{LITERATURA}

Aćimović, M. (2007). Filozofija mišljenja. Novi Sad: Futura publikacije.

Aćimović, M. (2015). Ogledi o srpskoj filozofiji I. Novi Sad: Akademska knjiga.

Bouhnik, D., Giat, Y. (2009). "Teaching High School Students Applied Logical Reasoning." Journal of Information Technology Education 8: 2-16.

Browne, N., Keeley, S. (2007). Asking the Right Questions. New Jersey: Pearson Prentice Hall.

Kalin, B. (1982). Logika i oblikovanje kritičkog mišljenja: uloga nastave Logike u oblikovanju kritičkog mišljenja. Zagreb: Školska knjiga.

Kuburić, A. (2010). „Nastava Logike u srednjoj školi - od 1950. do 2010.” Arhe 14: 183-195.

Kuburić, Z. (2004). Metodika verske nastave. Novi Sad: CEIR.

Marković, M. (2000). Logika za III razred gimnazije i pravno-birotehničke škole.

Beograd: Zavod za udžbenike i nastavna sredstva.

Smiljanić, D. (2016). Aporetika. Novi Sad: Akademska knjiga.

Smiljanić, D. (2012). „Obim ili kvalitet znanja? Komparacija metodoloških koncepata na primeru dva udžbenika". Tradicija nastave Filozofije Arhe 6: 55-77.

Šešić, B. (1977). Osnovi logike. Beograd: Naučna knjiga.

Anja Cmiljanović

University of Novi Sad

Faculty of Philosophy - PhD program in Philosophy

THE LOGIC OF MIHAJLO MARKOVIĆ AS A PHILOSOPHICAL PROPAEDEUTIC IN SECONDARY SCHOOL

\section{Summary}

In this paper we examined the possibility of the role of logic as a philosophical propaedeutic in the secondary school system of education. In the history of philosophy logic was most often understood as a science that deals with the basic elements and principles of thinking. If we have that in mind, it becomes understandable why it is necessary to study the logic before the students approach the subject of philosophy in the final year of the secondary school. Therefore, in this paper offered a short analysis and presentation of the textbook of Mihajlo Marković's logic for grammar schools and the third grade of the legal high school as a basic teaching tool in the teaching process of logic. In the introductory part of the paper, we dealt with the question of why logic should be considered as a philosophical propaedeutic. Afterwards, we devote focused on the textbook of Mihajlo Marković with respect to the elements of thinking and a general methodology of science. A brief analysis showed us how Marković considered it appropriate to approach 
the study of logic in secondary school. We discussed the methods that Marković used in his attempt to bring students closer to the basic elements of thinking: notion, judgment and conclusion, in a clear and comprehensible way. Finally, we also dealt with the way in which Marković introduces students to the basic concepts of scientific methodology, such as procedures in the field of scientific research, the notion of scientific explanation and scientific facts.

Key words: logic, philosophy, critical thinking, notion/concept, teaching, methodology, science, propaedeutic.

Primljeno: 15. 5. 2019.

Prihvaćeno: 26. 8. 2019. 